\title{
Serological Diagnosis of Toxoplasmosis in Household Cats in Egypt
}

\author{
R. A. Awad ${ }^{*}$ and A. M. A. Barakat*** \\ *Parasitology and Animal Diseases Department, Veterinary Research Division, \\ National Research Center, 33 Bohouth St., 12622 Dokki, Giza, Egypt. \\ **Department of Zoonotic Diseases, Veterinary Research Division, National Research \\ Center, 33 Bohouth St., 12622 Dokki, Giza, Egypt.
}

\begin{abstract}
$\mathbf{A}^{1}$
IM: the aim of this study is to use serological diagnosis for rapid detection of Toxoplasma gondii infection among household cats. Material and Methods: 212 serum samples collected from household cats of different sex, breeds and age groups in urban and rural area of Giza Province. Samples were checked by rapid chromatographic immune assay (IC) for detection of IgM and IgG antibodies against Toxoplasma gondii. Statistical analysis of the obtained results were carried out using Chi-square test to study the effect of sex, breed and age on the results. Results: the IgM antibodies against Toxoplasma gondii were detected in 19 cats $(8.96 \%)$, and $\mathrm{IgG}$ antibodies were detected in 63 cats $(29.71 \%)$, the overall positive were 82 cats (38.67), the sero prevalence against Toxoplasma gondii was high in Egyptian Mau breed and in cats of over one year age. Statistical evaluation of the results proved that there were significant differences between different sex, different cat breeds and different age groups. Conclusion: This study concluded that the serological diagnosis by IC for detecting IgM and IgG against Toxoplasma gondii, is a rapid, accurate method for diagnosis of Toxoplasmosis
\end{abstract}

Keywords: Serological diagnosis, Toxoplasmosis, Cats, rapid chromatographic immune assay (IC), Egypt .

\section{Introduction}

Toxoplasmosis is an infectious diseases caused by protozoal parasite called Toxoplasma gondii, which is an intracellular coccidian of apicomplexan phylum. This disease is a major zoonesis [1], with worldwide distribution [2].The role of domestic cats in spread of Toxoplasmosis is very critical because they are definitive host of this protozoal parasite where oocyte are shredded. All other mammalian hosts including human and birds considered as intermediate host [3].

After cats had infected, they shedded million of oocytes [4], consumption of food and water with shedded oocytes affect humans and livestock, leading to abortion, neonaltal mortalities and other congenital complications in human and animals [5].

In spite of the infection can occurred congenitally or by consumption of meat of infected animals with $T$. gondii, several studies concluded that $T$. gondii infection cannot maintained in the surrounding environment without presence of cats [6].
In human populations where pet cats were in close contact, seroprevalence of $\operatorname{IgM}$ and $\operatorname{IgG}$ antibodies agonist $T$. gondii should delivered [7].

Serosurvey of $T$. gondii specific antibodies in cats is much needed as it assess level of oocytes contamination of impacted environments [8].

This study was planned to study serological prevalence of T. gondii in house hold cats.

\section{Material and Methods}

Examined Animals

The 212 cats of different sex, breed and age as shown in Table 1.Were collected from many urban and rural districts in Giza province. These cats live in houses, cats visited Veterinary Clinic at $6^{\text {th }}$ October City, Giza Province for clinical check up and testing against Toxoplasmosis.

\section{Epidemiological data}

Epidemiological data regarding the age, area, hunting habit, access to outside, nature of pet cats food including uncooked meat like luncheon or no, were supplied by questionnaire and interview with the owners of pet cats according to Ahmed et al. [9], Sedlak and Bártová [10]. 
TABLE 1: Distribution of examined cats among different breeds, sex and age groups

\begin{tabular}{lcccccc}
\hline \multirow{2}{*}{ Breed } & \multicolumn{3}{c}{ Sex } & \multicolumn{3}{c}{ Age (month) } \\
\cline { 2 - 7 } & Male & Female & $\mathbf{3 - 6}$ & $\mathbf{6 - 9}$ & $\mathbf{9 - 1 2}$ & $>\mathbf{1 2}$ \\
\hline Persian & 51 & 47 & 8 & 18 & 22 & 50 \\
Main coon & 7 & 5 & 3 & 2 & 3 & 8 \\
Siam & 8 & 12 & 3 & 5 & 3 & 9 \\
Egyptian Mau & 20 & 22 & 5 & 4 & 8 & 25 \\
Mix breed & 18 & 20 & 3 & 11 & 4 & 20 \\
Total & 104 & 108 & 20 & 40 & 40 & 112 \\
\hline
\end{tabular}

\section{Sampling}

Blood samples were collected from Sephanous or juglar vien of examined pet cats with minimal doses of sedation according to Animal Welfare protocols (Ahmed et al. [9].

Collected blood samples centrifuged at 3000 rpm for is minutes for serum separation according to Ahmed et al. [9] and Sedlak and Bártová, [10].

\section{Serological diagnosis}

Rapid chromatographic immune assay (IC) was carried out for qualitative detection of Feline Toxoplasma $\operatorname{IgM}$ and $\operatorname{IgG}$ antibodies in Feline serum [11]. One step Feline Toxoplasma IgM and IgG test kit supplied by Bionote, Korea.

\section{Statistical analysis}

Statistical analysis was done using Chi-square test to study effect of sex, age and breed according to Smith [12].

\section{$\underline{\text { Results }}$}

The results of rapid chromatographic immune assay (IC) are shown in Table 2 which includes distribution of $\operatorname{IgM}$ and $\mathrm{IgG}$ antibodies presence in different 4 serological groups. The percentages of each group to the total number of examined cats were $3.77 \%, 25.94 \%, 5.18 \%$ and $61.32 \%$ for first group $[\operatorname{IgM}(+v e) \operatorname{IgG}(+v e)]$, second group $[\operatorname{IgM}(-v e) \operatorname{IgG}(+v e)]$, third group [IgM (+ev) $\operatorname{IgG}(-\mathrm{ev})]$ and fourth group [IgM (-ev) $\operatorname{IgG}(-\mathrm{ve})]$, respectively.

TABLE 2. Number of IgM and IgG positive pet cats

\begin{tabular}{lcc}
\hline \multirow{2}{*}{ Sero-groups } & \multicolumn{2}{c}{ Cats } \\
\cline { 2 - 3 } & Number & Percentage (\%) \\
\hline IgM (+ve) IgG (+ve) & 8 & 3.77 \\
$\operatorname{IgM}(-\mathrm{ve}) \operatorname{IgG}(+\mathrm{ve})$ & 55 & 25.94 \\
$\operatorname{IgM}(+\mathrm{ve}) \operatorname{IgG}(-\mathrm{ve})$ & 11 & 5.18 \\
IgM (-ve) IgG (-ve) & 130 & 61.32 \\
Tota IgM (+ve) & 19 & 8.96 \\
Total IgG (+ve) & 63 & 29.71 \\
Overall (+ve) & 82 & 38.67 \\
Total & 212 & -- \\
\hline
\end{tabular}

Table 3 indicates distribution of positive reactors (overall positive) among male and female cats: 39 positive reactors were recorded in males, while 43 positive reactors were recorded among female cats.
Table 4 illustrates distribution of positive reactors among different breeds. It showed 33, 5, 6, 24 and 14 positive, while 65, 9, 14, 18 and 24 were negative in Persian, Main coon, Siam, Egyptian Mau and mix breed, respectively. 
TABLE 3. Positive cats (overall positive) among different sex

\begin{tabular}{lcc}
\hline \multirow{2}{*}{ Sex } & \multicolumn{2}{c}{ Cats } \\
\cline { 2 - 3 } & Positive & Negative \\
\hline Male & 39 & 65 \\
Female & 43 & 65 \\
Total & 82 & 130 \\
\hline
\end{tabular}

TABLE 4. Distribution of overall positive reactor cats among different breeds

\begin{tabular}{|c|c|c|c|}
\hline \multirow{2}{*}{ Breed } & \multicolumn{2}{|c|}{ Cats } & \multirow{2}{*}{ Total } \\
\hline & Positive & Negative & \\
\hline Persian & 33 & 65 & 98 \\
\hline Main coon & 5 & 9 & 14 \\
\hline Siam & 6 & 14 & 20 \\
\hline Egyptian Mau & 24 & 18 & 42 \\
\hline Mix breed & 14 & 24 & 38 \\
\hline Total & 82 & 130 & 212 \\
\hline
\end{tabular}

Table 5 illustrates distribution of positive reactors among different age groups. It showed $48,18,12$ and 4 positive, while $64,22,28$ and 16 were negative in over 12 months, 9-12 months, 6-9 months and 3-6 months, respectively.

\section{Statistical analysis}

Statistical analysis using Chi-square test to study the effect of sex proved that there was significant difference between male and female cats $(\mathrm{P} \leq 0.05)$.

TABLE 5. Distribution of overall positive reactor cats among different age group

\begin{tabular}{lcccc}
\hline \multirow{2}{*}{ Results } & \multicolumn{3}{c}{ Age group (months) } \\
\cline { 2 - 5 } & $\mathbf{3 - 6}$ & $\mathbf{6 - 9}$ & $\mathbf{9 - 1 2}$ & Over 12 \\
\hline Overall positive & 4 & 12 & 18 & 48 \\
Overall negative & 16 & 28 & 22 & 64 \\
Total & 20 & 40 & 40 & 112 \\
\hline
\end{tabular}

Chi-square test was also used to study the effect of breed and age on the results of the examined cats. We found that both breed and age had effects on the results by another mean there were significant differences between different cat breeds or different age group $(\mathrm{P}<0.05)$.

\section{Discussion}

In this study serological diagnosis used by applying rapid IC for detection of both IgM and IgG antibodies against Toxoplasma gondii in sera of examined cats was rapid and accurate method for diagnosis, as recommended by Ahmad et al., Luo et al. $[9,11]$.

Toxoplasmosis in cats present in acute or chronic form as stated by Gaskell et al., Shaw and Ihle [13, 14]. Rapid IC assay succeeded in detection of IgM antibodies against Toxoplasma gondii in 19 cats $(8.96 \%)$. Theses 19 IgM sero positive cats represented the acute form of $T$. gondii infection [15], while 63 cats $(29.71 \%)$ were positive for $\mathrm{IgG}$ antibodies against $T$. gondii represented the chronic form $[16,17]$.

The 82 sero positive cats considered as overall positive as with a percentage (38.67\%) among population of this study, similar results recorded by several authors $[9,18-26]$ in different geographical parts all over the world.

The results recorded that there was significance difference between different age Egypt. J. Vet. Sci. Vol. 50, No.1 (2019) 
groups, by another mean age has significance effect on the on the prevalence of Toxoplasmosis, but higher percentage was detected in cats over 1 year in age and this may be attributed to multiple exposures of these old cats for infection [27, 28]. While number of overall positive cats decrease with decrease in age significantly due to less exposure times [27].

The overall positive reactors were high in certain breed like Egyptian Mau and Mix breed. These findings attributed to hunting habits and getting outdoor to houses gardens as mentioned by Gyroke et al. [29] and Opsteeg et al. [30].

Statistical analysis were carried out to study the effect of sex, age and breed using Chi-Square Test. Smith [12].

There are significant differences detected between different sex, breed and age group, respectively as stated by Awad et al. [31].

Conclusion: Toxoplasmosis is well known as major zoonosis, causes fatal health problems for human. Cats considered major source for human infection and environment contamination. Toxoplasmosis cannot be diagnosed clinically in cats, so serological diagnosis is the only rapid and accurate method for detection of Toxoplasma gondii infection in household cats.

\section{Acknowledgments}

The author is grateful for Prof. Dr. Sobhy Abd-Elshafy, Parasitology and Animal Diseases Department, Veterinary Division, National Research Center, Giza, Egypt, for providing the technical and scientific consultant regarding statistical analysis of data. The author also is grateful for Prof. Dr. Wagdy K. B. Khalil for his great help in finalizing of this manuscript. The present study received no financial support.

\section{Conflict of Interest Statement}

The author whose name is listed immediately below certify that he has no affiliations with or involvement in any organization or entity with any financial interest (such as honoraria, educational grants, participation in speakers' bureaus, membership, employment, consultancies, stock ownership, or other equity interest, and expert testimony or patent-licensing arrangements), or non-financial interest (such as personal or professional relationships, affiliations, knowledge or beliefs) in the subject matter or materials discussed in this manuscript.

\section{Author contribution}

The authors performed the study plan and design. Romane Adieb Awad and Ashraf Barakat collected the samples from the clinic, and had carried out the clinical examination and IC laboratory work. Romane Adieb Awad had done all issues of writing, revising, and improvement of the article for publication.

\section{Ethical consideration}

The owners of cats were informed and permission was received from them. The cats included in this study for taking samples used in this work. Samples were collected as per standard sample collection procedure without any harm to animals. The proposal of this study had approval from National Research Center committee no: 10/03/2017.

\section{References}

1. Dubey J.P., Toxoplasmosis in Animals and Humans, $2^{\text {nd }}$ ed., CRC Press, New York. (2016).

2. Lindsay D.S. and Weiss L.M., Opportunistic infections: Toxiplasma, Sarcocystis, and Microsporidia. Springer Science \& Business Media (2008).

3. Dubey J.P., Toxoplasmosis - a waterborne zoonosis. Veterinary Parasitology, 126, 57-72 (2004).

4. Dabritz H.A., Miller M.A., Atwill, E.R. Gardner I.A., Leutenegger C.M., Melli, A.C. and Conrad P.A., Detection of Toxoplasma gondii-like oocysts in cat feces and estimates of the environmental oocyst burden. Journal of American Veterinary Medical Association, 23, 1676-1684 (2007).

5. Afonso E., Thulliez P. and Gilot-Fromont E., Transmission of Toxoplasma gondii in an urban population of domestic cats (Felis catus). International Journal of Parasitology, 36, 13731382 (2006).

6. Dubey J.P., Rollor E.A., Smith K., Kwok O.C. and Thulliez, P., Low seroprevalence of Toxoplasma gondii in feral pigs from a remote island lacking cats. Journal of Parasitology, 83, 839-841 (1997).

7. Pereira L.H., Staudt M., Tanner C.E. and Embil J.A., Exposure to Toxoplasma gondii and cat ownership in Nova Scotia. Pediatrics, 89, 11691172 (1992).

8. Miro G., Montoya A., Jimenez S., Frisuelos C., Mateo M. and Fuentes I., Prevalence of antibodies 
to Toxoplasma gondii and intestinal parasites in stray, farm and household cats in Spain. Veterinary Parasitology, 126, 249-255 (2004).

9. Ahmad N., Ahmed H., Irum S. and Qayyum M., Seroprevalence of $\operatorname{IgG}$ and $\operatorname{IgM}$ antibodies and associated risk factors for toxoplasmosis in cats and dogs from subtropical arid parts of Pakistan. Tropical Biomedicine, 31(4), 777-784 (2014)

10. Sedlak K. and Bártová E., The prevalence of Toxoplasma gondii IgM and IgG antibodies in dogs and cats from the Czech Republic. Veterinárni medicina 51(12), 555-558 (2006).

11. Luo J., Sun H., Zhao X., Wang S., Zhuo X., Yang Y., Chen X., Yao C. and Du A., Development of an immunochromatographic test based on monoclonal antibodies against surface antigen 3 (TgSAG3) for rapid detection of Toxoplasma gondii. Vet Parasitol., 252, $52-57$ (2018).

12. Smith R.D., Veterinary Clinical Epidemiology. 3rd ed. CRC Press, Boca Raton., (2005).

13. Gaskell R.M., Tennant B., Bennett M. and Willoughby K., Feline and Canine Infectious Diseases. Published by Iowa State Press, Ames, IA., (1996).

14. Shaw D.H. and Ihle S.L., Small animal internal medicine, published by Williams and Wilkins, 1997, chapter 47, p 464-468.

15. Dubey J.P., Greene C.E. and Lappin M.R., Toxoplasmosis and Neosporosis. In: C.E. Greene, editor. Infectious Disease f the Dog and Cat.1st ed. United States of America. Saunders., pp. 818-829 (1990).

16. Gauss C.B.L., Almería S., Ortuño A., Garcia F. and Dubey J.P., Seroprevalence of Toxoplasma gondii antibodies in domestic cats from Barcelona, Spanish Journal of Parasitology, 89, 1067-1068 (2003).

17. Tizard I.R., Veterinary immunology an introduction, seventh edition: Chapter 21 pp: 247258. , chap.24, pp. 281-292, (2004).

18. Maruyama S., Kabeya H., Nakao R., Tanaka S., Sakai T., Xuan X., Katsube Y. and Mikami T., Seroprevalence of Bartonella henselae, Toxoplasma gondii, FIV and FeLV infections in domestic cats in Japan. Microbiology and Immunology, 47, 147-153 (2003).

19. Pena H.F.J., Soares R.M., Amaku M., Dubey J.P. and Gennari S.M., Toxoplasma gondii infection in cats from Sao Paulo state, Brazil: Seroprevalence, oocyst shedding, isolation in mice, and biologic and molecular characterization. Research in Veterinary Science, 81, 58-67 (2006).

20. Zhang H., Zhou D.H., Zhou P., Lun Z.R., Chen X.G., Lin R.Q., Yuan Z.G. and Zhu X.Q., Seroprevalence of Toxoplasma gondii infection in stray and household cats in Guangzhou, China. Zoonosis and Public Health, 56, 502-505 (2009).

21. Uggla A., Mattson S. and Juntti N., Prevalence of antibodies to Toxoplasma gondii in cats, dogs and horses in Sweden. Acta Veterinaria Scandinavica, 31, 219-222 (1990).

22. Klein B.U. and Muller E., Seroprevalence of antibodies to Neospora caninum in dogs with and without clinical suspicion for neosporosis in Germany. Raktische Tierarzt, 82, 437-440 (2001).

23. Tenter A.M., Vietmeyer C., Johnson A.M., Janitschke K., Rommel M. and Lehmacher W., Elisas based on recombinant antigens for seroepidemiological studies on Toxoplasma gondii infections in cats. Parasitology, 109, 29-36 (1994).

24. Roze M., Feline uveitis: A clinical and serological study of 44 cases. Pratique Médicale et Chirurgicale de l'Animal de Compagnie, 33, 123130 (1998).

25. Lee S.E., Kim J.Y., Kim Y.A., Cho S.H., Ahn H.J., Woo H.M., Lee W.J. and Nam H.W., Prevalence of Toxoplasma gondii infection in stray and household cats in regions of Seoul, Korea. Korean Journal of Parasitology, 48, 267-270 (2010).

26. Raeghi S., Sedeghi S. and Sedeghi S., Prevalence of Toxoplasma gondii antibodies in cats in Urmia, northwest of Iran. Journal of Animal and Plant Science, 21: 132-134 (2011).

27. Cabral, D.D., Silva, D.A.O., Mineo, J.R., Ferreira, F.A. \& Duran, F.P. Frequency of anti-Toxoplasma gondii antibodies in apparently dogs of the city of Uberlandia-M.G, Brazil. Veterinary Parasitology, 7, 87-90(1998).

28. Wu S.M., Huang S.Y., Fu B.Q., Liu G.Y., Chen J.X., Chen M.X., Yuan Z.G., Zhou D.H., Weng Y.B., Zhu X.Q. and Ye D.H., Seroprevalence of Toxoplasma gondii infection in pet dogs in Lanzhou, Northwest China. Parasite and Vector, 4, 64 (2011).

29. Gyorke A., Opsteegh M., Mircean V., Iovu A. and Cozma V., Toxoplasma gondii in Romanian Egypt. J. Vet. Sci. Vol. 50, No.1 (2019) 
household cats: Evaluation of serological tests, epidemiology and risk factors. Preventive Veterinary Medicine, 102, 321-328 (2011).

30. Opsteegh M., Havemana R., Swarta A.N., MensinkBeerepoota M.E., Hofhuisa A., Langelaara M.F.M. and Giessena J.W.B., Seroprevalence and risk factors for Toxoplasma gondii infection in domestic cats in The Netherlands. Preventive Veterinary Medicine, 104, 317-326 (2012).

31. Awad R.A., Khalil W.K.B. and Attallah A.G., Epidemiology and diagnosis of feline panleukopenia virus in Egypt: Clinical and molecular diagnosis in cats. Veterinary World, 11 (5), 578-584 (2018).

(Received 11/04/2019; accepted 22/04/2019) 


\title{
التشخيص السيرولوجى لمرض التكسويلازما فى القطط المنزلية فى مصر \\ رومانى اديب عوض*و اشرف محمد بركات*"

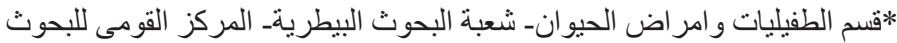

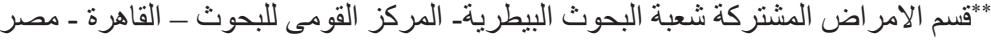

\begin{abstract}
هذه الدر اسة تهدف الى استخدام التشخيص السيرولوجى للاكتشاف السريع لطفيل التكسو بلازما جو ندى فى القطط

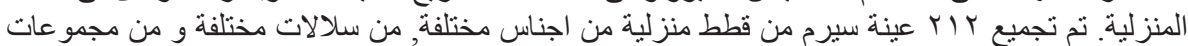

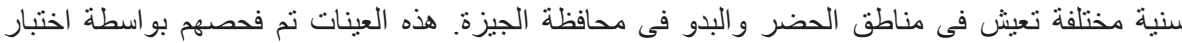

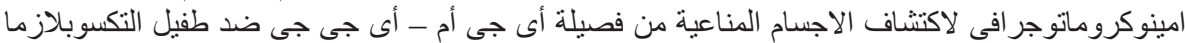

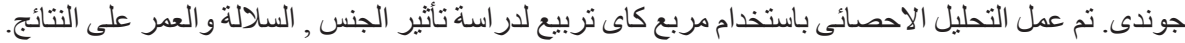

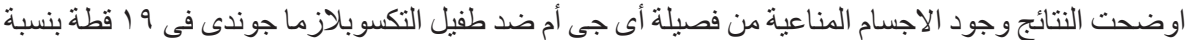

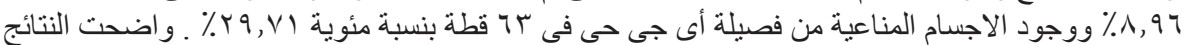

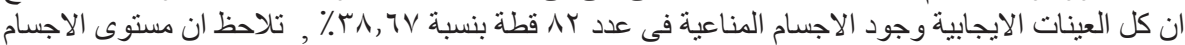

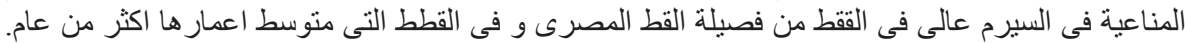

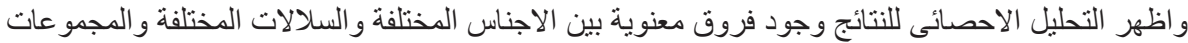

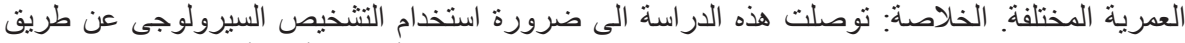

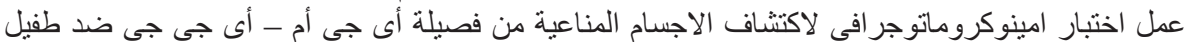

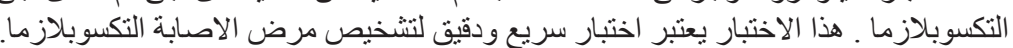

